\title{
Fruit availability at the individual and local levels influences fruit removal in Cecropia pachystachya
}

\author{
A. B. Navarro ${ }^{*}$, A. A. A. Bovo ${ }^{a}$, E. R. Alexandrino, , V. C. Oliveira ${ }^{a}$, M. A. Pizo \\ and K. M. P. M. B. Ferraz ${ }^{a}$
}

${ }^{a}$ Laboratório de Ecologia, Manejo e Conservação de Fauna Silvestre - LEMaC, Escola Superior de Agricultura "Luiz de Queiroz" - ESALQ, Universidade de São Paulo - USP, Av. Pádua Dias, 11, CEP 13418-900, Piracicaba, SP, Brasil

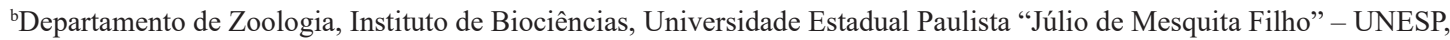
Av. 24-A, 1515, CEP 13506-900, Rio Claro, SP, Brasil

*e-mail: ana.navarro@usp.br

Received: May 9, 2018 - Accepted: August 10, 2018 - Distributed: November 30, 2019

Bird frugivory is modulated by environmental variables, wherein some variables are related to plant species and some are related to the surrounding habitat (Saracco et al., 2005; Pizo and Almeida Neto, 2009; Gagetti et al., 2016). Although several studies have investigated the influence of such variables on fruit removal by birds, no study focused on Cecropia, an emblematic plant genus and one of the most preferred food sources for frugivorous animals in the Neotropical region (Oniki et al., 1994).

Cecropia pachystachya Trécul (Urticaceae), as other species of the genus, is a common plant typical of the initial phases of ecological succession that attracts many frugivorous animals. Some studies have investigated the relationship between frugivorous birds and C. paschystachya (Marcondes-Machado and Oliveira, 1988; Gonçalves and Vitorino, 2014). Nevertheless, there is a lack of studies that investigate the influence of individual and habitat features on the removal of C. paschystachya fruits by birds. Therefore, our main goal was to record the interactions between birds and $C$. paschystachya to examine which variables (height, crop size and richness of plant species fruiting nearby) may influence bird frugivory events.

We conducted the study at a human-modified landscape

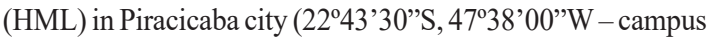
"Luiz de Queiroz"/University of São Paulo), São Paulo state. This HML has approximately 900 ha and is composed by a mix of urban and rural areas, that surrounds small semi-deciduous forest remnants (interior Atlantic Forest Biome) and reforested areas (Klaus, 2001). We selected eight individuals of $C$. paschystachya with ripe fruits, absence of mutualist ants living in the trunk, and distant at least $10 \mathrm{~m}$ from any other fruiting C. paschystachya, inside five forest remnants ranging from 1.3 to 12 ha. We recorded three variables that may influence bird frugivory according to other studies that also investigated these variables in bird-plant interactions (e.g. Saracco et al., 2005; Pizo and Almeida-Neto, 2009; Flörchinger et al., 2010), two intrinsic to the individual plant (height and crop size) and one related to the surrounding habitat (richness of zoochoric plant species fruiting in a $100 \mathrm{~m}^{2}$ plot around each individual). We sampled bird-plant interactions during a total of 80 hours of observation on focal plants, ten hours per plant. We considered a bird frugivory event every time a bird visited the focal plant to consume fruits. We estimated crop size by counting the number of catkins before the start of frugivory observations.

We run a Pearson correlation test to assess the relationship between independent variables and the absolute number of bird frugivory events, considering $\mathrm{P}<0.05$ as the significance level. We also run a linear mixed model analysis to select the variables that best explain bird frugivory events. We used the Akaike's Information Criterion with small-sample correction (AICc) to select the best models (i.e., $\triangle \mathrm{AICc}$ values $<2$ ). We also calculated wAIC values, which represents the chance for the model to be selected varying from 0 to 1 .

We observed a total of 480 feeding visits performed by 19 bird species and recorded six different zoochoric plant species fruiting nearby the focal C. paschystachya trees (Citharexylum myrianthum Cham., Psidium guajava L., Schinus terebinthifolius Raddi, Solanum granulosoleprosum Dunal, Syzygium cumini (L.) Skeels and Trema micrantha (L.) Blume). There was a positive correlation between bird frugivory events and crop size $(\mathrm{R}=0.79, \mathrm{P}=0.018)$ and richness of plant species fruiting nearby $(\mathrm{R}=0.79, \mathrm{P}=0.019)$, but no correlation between plant height and bird frugivory events was found $(\mathrm{P}>0.05)$. Crop size $(\mathrm{AICc}=81.9, \triangle \mathrm{AICc}=0.00$, WAIC $=0.414)$ and richness of plant species fruiting nearby $(\mathrm{AICc}=82.1, \Delta \mathrm{AICc}=0.15$, wAIC $=0.383)$ were the variables that best explained the frequency of bird frugivory events.

By providing a higher amount of food, a higher fruit crop size represents a better opportunity for foraging of frugivorous birds. Indeed, crop size has been shown to exert a positive and pervasive influence on the attraction of frugivorous birds to fruiting plants (Saracco et al., 2004). On the other hand, plants fruiting simultaneously at the same area are sometimes considered competitors, especially for seed-dispersal agents (Wright, 2002). However, our results revealed that this variable also affected positively the frequency of bird frugivory events at $C$. paschystachya. This finding corroborates studies that reported facilitation between neighboring fruiting plants 
(Saracco et al., 2005; Albrecht et al., 2015). Although the height of C. paschystachya individuals were not correlated with bird frugivory events, the plant height may influence the forest stratification and the forest habitat, consequently influencing the strength of plant-frugivore interaction and fruit availability (Schleuning et al., 2011). Thus we reinforce the importance of better investigating the influence of this variable due to variation depending on plant species (e.g., Traveset, 1994; Flörchinger et al., 2010).

In conclusion, our study reinforces the importance of resource availability at the individual and neighborhood scales to attract frugivorous birds to fruiting C. paschystachya. Considering that this plant species is important at initial phases of ecological succession and very attractive to birds, it is relevant to know that offering more fruits at the neighborhood scale enhances the frequency of bird frugivory events, a knowledge useful for managers aiming to attract frugivores and the seeds they carry to restoration areas where $C$. pachystachya may be planted.

\section{Acknowledgements}

We are thankful to Herbarium of Luiz de Queiroz College of Agriculture (ESALQ - University of São Paulo). We also thank Gabriel D. Colletta for assistance on plant identification and Alexander V. Christianini for his contributions to this research. Katia M. P. M. B. Ferraz and Marco A. Pizo are funded by Conselho Nacional de Pesquisa e Desenvolvimento Científico e Tecnológico (CNPq) research grant (processes 308503/2014-7 and 304244/2016-3, respectively).

\section{References}

ALBRECHT, J., BOHLE, V., BERENS, D.G., JAROSZEWICZ, B., SELVA, N. and FARWIG, N., 2015. Variation in neighbourhood context shapes frugivore-mediated facilitation and competition among co-dispersed plant species. Journal of Ecology, vol. 103, no. 2, pp. 526-536. http://dx.doi.org/10.1111/1365-2745.12375.

FLÖRCHINGER, M., BRAUN, J., BÖHNING-GAESE, K. and SCHAEFER, H.M., 2010. Fruit size, crop mass, and plant height explain differential fruit choice of primates and birds. Oecologia, vol. 164, no. 1, pp. 151-161. http://dx.doi.org/10.1007/ s00442-010-1655-8. PMid:20490552.

GAGETTI, B.L., PIRATELLI, A.J. and PIÑA-RODRIGUES, F.C.M., 2016. Fruit color preference by birds and applications to ecological restoration. Brazilian Journal of Biology $=$ Revista
Brasileira de Biologia, vol. 76, no. 4, pp. 955-966. http://dx.doi. org/10.1590/1519-6984.05115. PMid:27166566.

GONÇALVES, G.L. and VITORINO, B.D., 2014. Comportamento alimentar de aves em Cecropia pachystachya Trécul (Urticacea) em um ambiente urbano no município de Luz, Minas Gerais, Brasil. Biota Amazônia, vol. 4, no. 3, pp. 100-105. http://dx.doi. org/10.18561/2179-5746/biotaamazonia.v4n3p100-105.

KLAUS, R. 2001. ESALQ 100 anos, um olhar entre o passado e o futuro. São Paulo: Prêmio Editorial.

MARCONDES-MACHADO, L.O. and OLIVEIRA, M.M.A., 1988. Comportamento alimentar de aves em Cecropia (Moraceae), em Mata Atlântica, no Estado de São Paulo. Revista Brasileira de Zoologia, vol. 4, no. 4, pp. 331-339. http://dx.doi.org/10.1590/ S0101-81751987000400005.

ONIKI, Y., MELO JUNIOR, T.A., SCOPEL, E.T. and WILLIS, E.O., 1994. Bird use of Cecropia (Cecropiaceae) and nearby trees in Espirito Santo State, Brazil. Ornitologia Neotropical, vol. 5, pp. 109-114.

PIZO, M.A. and ALMEIDA NETO, M., 2009. Determinants of fruit removal in Geonoma pauciflora, an understory palm of neotropical forests. Ecological Research, vol. 24, no. 6, pp. 11791186. http://dx.doi.org/10.1007/s11284-009-0599-0.

SARACCO, J.F., COLLAZO, J.A. and GROOM, M.J., 2004. How do frugivores track resources? Insights from spatial analyses of bird foraging in a tropical forest. Oecologia, vol. 139, no. 2, pp. 235-245. http://dx.doi.org/10.1007/s00442-004-1493-7. PMid:14872335.

SARACCO, J.F., COLLAZO, J.A., GROOM, M.J. and CARLO, T.A., 2005. Crop size and fruit neighborhood effects on bird visitation to fruiting Schefflera morototoni trees in Puerto Rico. Biotropica, vol. 37, no. 1, pp. 81-87. http://dx.doi.org/10.1111/ j.1744-7429.2005.04040.x.

SCHLEUNING, M., BLÜTHGEN, N., FLÖRCHINGER, M., BRAUN, J., SCHAEFER, H.M. and BÖHNING-GAESE, K., 2011. Specialization and interaction strength in a tropical plantfrugivore network differ among forest strata. Ecology, vol. 92, no. 1, pp. 26-36. http://dx.doi.org/10.1890/09-1842.1. PMid:21560673.

TRAVESET, A., 1994. Influence of type of avian frugivory on the fitness of Pistacia terebinthus L. Evolutionary Ecology, vol. 8, no. 6, pp. 618-627. http://dx.doi.org/10.1007/BF01237845.

WRIGHT, J.S., 2002. Plant diversity in tropical forests: a review of mechanisms of species coexistence. Oecologia, vol. 130, no. 1, pp. 1-14. http://dx.doi.org/10.1007/s004420100809. PMid:28547014. 